\title{
New Directions in Management Accounting Research: Insights from Practice
}

\author{
Frank H. Selto \\ University of Colorado at Boulder and University of Melbourne \\ Sally K. Widener \\ Rice University
}

August 2002

We acknowledge and thank Shannon Anderson, Phil Shane, Naomi Soderstrom and participants at the 2002 MAS mid-year meeting, a University of Colorado at Boulder workshop and the AAANZ-2001 conference for their comments and suggestions for this paper.

Appears in Advances in Management Accounting, 2004 


\title{
New Directions in Management Accounting Research: Insights from Practice
}

\begin{abstract}
Although the "new economy" once again resembles the old economy, the drivers of success for many firms continue to be intangible or service-related assets. These changes in the economic basis of business are leading to changes in practice which are creating exciting new opportunities for research. Management accounting still is concerned with internal uses of and demands for operating and performance information by organizations, their managers, and their employees. However, current demand for internal information and analysis most likely reflects current decision making needs, which have changed rapidly to meet economic and environmental conditions. Many management accounting research articles reflect traditional research topics that might not conform to current practice concerns. Some accounting academics may desire to pursue research topics that reflect current problems of practice to inform, influence, or understand practice or influence accounting education.

This study analyzes attributes of nearly 2,000 research and professional articles published during the years 1996-2000 and finds numerous, relatively unexamined research questions that can expand the scope of current management accounting research. Analyses of theories, methods, and sources of data used by published management accounting research also describe publication opportunities in major research journals.
\end{abstract}

\section{Data Availability}

Raw data are readily available online, and coded data are available upon request from the authors. 


\section{New Directions in Management Accounting Research: Insights from Practice}

\section{Introduction and Motivation}

While some aspects of the "new economy" reflected an unrealistic bubble, many firms continue to be driven by intangible assets, the highly competitive global economy, and increasing technological change to forge changes in what accountants have thought of as their "traditional" accounting responsibilities. In many cases, accountants and financial staff are leading the way in changing their internal roles. Accountants find themselves managing new business practices, such as outsourcing, focusing more on cost control and process re-engineering, and expanding their involvement with strategic planning and implementation. The expansion of accountants' duties beyond traditional budgeting and reporting is occurring rapidly and is creating numerous opportunities for academic management accountants to conduct innovative research.

According to a recent IMA study of practicing "management accountants" [IMA, 2000], ${ }^{1}$ apparently no management accountants are left in practice. Professionals in practice overwhelmingly have favored job titles such as financial analyst, business advisor, and consultant over "cost accountant" or “management accountant." Perhaps this is not a purely cosmetic change. The IMA study also shows that current job titles reflect broader duties than traditionally executed by accountants. Instead of viewing this change as the end of management accounting, a more optimistic viewpoint is to see this as an opportunity to broaden management accounting, both in education and in research. This opens doors for exciting new research opportunities.

Some accounting researchers conduct research that is explicitly oriented to or has application to practice. Others might seek to do so. Several related motivations or objectives for practice-oriented research include desires to (1) gain increased understanding of why organizations use certain techniques and practices, (2) gain increased understanding of how and which techniques used in practice impact organizational performance, (3) inform practitioners, (4) increase the applicability of accounting textbooks, coursework, and programs (5) satisfy personal taste, (6) and increase consulting opportunities. While researchers pursuing any of these might find this study interesting and helpful, this study is explicitly motivated by the first four objectives.

One desirable outcome of practice-oriented research may be a positive impact on accounting enrollments. Many university accounting programs in the US are in decline, perhaps because of (1) increased education requirements for accounting certification in many states, (2) relatively greater

\footnotetext{
${ }^{1}$ See www.imanet.org/content/Publications_and_Research/IMAstudies/moreless.pdf
} 
employment opportunities and salaries in other business fields, such as finance, (3) competitive educational efforts by industrial and professional firms, (4) focused financial support of only select universities by employers of accounting graduates, and (5) perceived greater job-relevance of other courses. Many of the factors that can contribute to declining enrollments in accounting are beyond the control of accounting academics. Because research surely informs teaching, accounting faculty might help increase accounting enrollments by managing what is researched. ${ }^{2}$

\section{Research Objectives}

Management accounting research, researchers, and education (and perhaps other accounting subfields by analogy) might benefit from identifying interesting, less researched topics that reflect issues of current practice. More influence on external constituents might lead to greater prestige, esteem, and resources for researchers, and, perhaps, improvements in practice [e.g., Anderson, 1983]. The objective of this study is to use observed divergences between management accounting research topics and issues of practice to identify interesting, practice-oriented research questions.

The study assesses and interprets correspondence (or lack thereof) between published research topics and topics of the practice literature. High correspondence can be misleading because it might represent good synergy, coincidence, or little interest. Low correspondence might present opportunities for interesting new research. Thus, this study examines both types of topics as potential sources of interesting research questions. Finally, the study then addresses the equally important issue of matching these research questions with theory, data, and research methods. Without these matches, management accounting research will have difficulty moving beyond pure description or endless theory building. It also might be possible to increase the probability of publication of these new questions by assessing journals' past publication histories.

This study is unlike recent, more focused reviews of management accounting research, which include Covaleski and Dirsmith [1996] - organization and sociology-based research; Elnathan et al. [1996] benchmarking research; Shields [1997] - research by North Americans; Demski and Sappington [1999] empirical agency theory research; Ittner and Larcker [1998] - performance measurement research; and Ittner and Larker [2001] - value-based management research. The present study is in the spirit of Atkinson et al. [1997], which seeks to encourage broader investigations of management accounting research topics. The present study extends Atkinson et al. by documenting and identifying practiceoriented, innovative research questions in major topic areas based on observed divergences between practice and research.

\footnotetext{
${ }^{2}$ Although the data are available, we have resisted the temptation to classify the practice orientation of management accounting researchers or educational institutions.
} 


\section{Research Design and Method}

The study's research design is to first compare topic coverage of research and professional publications. Differences between research and practice topics are indications of correspondence between the domains of inquiry. The study measures correspondence by levels and changes in relative topic coverage. The study further analyzes research articles' use of theory, sources of data, and methods of analysis, which are sorted by topic and publication outlet. The remainder of this section describes the study's research domain, sampling plan, data collection, and data analysis.

\section{Research Domain}

The study's research domain is limited to published articles that address conventional management accounting topics (i.e., as reflected in management accounting textbooks) plus several that additionally are salient in the professional financial and accounting literature (described in the next section). Both published research and practice topics are assumed to be reasonable proxies of issues and questions of interest to researchers and practitioners. Several problems arise in the use of these proxies. (1) It is well known that time between completion and publication of articles differs between the research and practice literatures. This study examines various time lags between research and practice topics to account for the publication lag. (2) Not all research efforts or practice issues appear in the published literature. This study assumes that unpublished research articles do not meet academic quality standards, although some researchers might harbor other explanations. This study also compares the practice literature to the IMA's study of practice to confirm conformance between the practice literature and issues expressed by surveyed practitioners (see footnote $\# 2$ and the later discussion of aggregate results).

The study considers an article to be of direct interest to "management accountants" if it addresses one or more of the following topics:

- Accounting software

- Budgeting

- Business process improvement

- Cash management

- Compensation plans

- Cost accounting

- Cost management

- Effects of financial reporting on internal systems
- Effects of information technology on internal systems

- Improving profits

- Internal control

- Management accounting practices

- Management control

- Outsourcing

- Performance measurement

- Research methods

- Shareholder value 


\section{Sampling}

The study analyzes articles that appeared in print during the years 1996-2000. This five-year period witnessed dramatic changes in technology, business conditions, and the responsibilities of financial and accounting professionals. There is no reason to believe that future years will be any less volatile. The study further defines the domain of management accounting research as articles fitting the above topics that were published in the following English-language research journals:

- Academy of Management Journal (AMJ)

- Academy of Management Review (AMR)

- Accounting and Finance (A\&F)

- Accounting Organizations and Society (AOS)

- Advances in Management Accounting (AIMA)

- Contemporary Accounting Research (CAR)

- Journal of Accounting, Auditing, and Finance
- Journal of Accounting and Economics (JAE)

- Journal of Accounting Research (JAR)

- Journal of Management Accounting Research (JMAR)

- Management Accounting Research (MAR)

- Review of Accounting Studies (RAS)

- Strategic Management Journal (SMJ)

- The Accounting Review (TAR) (JAAF)

We assume that the research literature in other languages either covers similar topics or is not related to the practice literature aimed at English-speaking professionals. ${ }^{3}$

Similarly, the study defines the domain of management accounting practice to be articles fitting the topical boundaries that were published in English-language professional magazines and journals aimed at financial managers, executives, and consultants. We, therefore, assume that articles published in the professional literature accurately reflect issues of importance to professionals themselves. The professional literature sources include:

- $\quad$ Strategic Finance (SF)

- Management Accounting (MA-US and UK)

- Journal of Accountancy (JOA)

- Financial Executive (FE)

\section{Data Collection}

The study uses the online, electronic contents of the abstracts of management accounting articles from research and practice journals published during the years 1996-2000 as its source of data. The study includes the entire contents of explicitly named management accounting journals (e.g., Advances in

\footnotetext{
${ }^{3}$ Some management accounting researchers are placing work in other management and operations journals, such as Management Science. Omitting these articles could be a source of sampling bias if this is a growing trend.
} 
Management Accounting, Strategic Finance) and selected articles from other journals and magazines if articles matched the topic domain. The database of management accounting articles consists of information on

- 373 research articles

- $\quad 1,622$ professional or practice articles

\section{Data Analysis}

Qualitative method. The study uses a qualitative method to label, categorize, and relate the management accounting literature data [e.g., Miles and Huberman, 1994]. The study uses Atlas.ti software [www.atlasti.de], which is designed for coding and discovering relations among qualitative data. ${ }^{4}$ The study began with predetermined codes based on the researchers' expectations of topics, methods, and theories. As normally happens in this type of qualitative study, the database contains unanticipated qualitative data that required creation of additional codes. This necessary blend of coding, analysis, and interpretation means that the coding task usually cannot be outsourced to disinterested parties. Thus, this method is unlike content analysis, which counts pre-defined words, terms, or phrases.

Table 1 contains the complete list of research-literature codes used in this study. The practice literature codes are identical except for journal codes. Codes shown in capital letters (e.g., ARTICLE) are major codes, or "supercodes," that contain related minor or subcodes (e.g., article-ABSTRACT). An "other" code collects topics that apparently are of minor interest at this time. Figure 1 displays sample information related to one of the data records. The left-hand panel shows a typical article's data, while the right-hand panel contains the codes applied by the researchers to the data. An article may cover several topics and use several methods and theories; thus the numbers of topic, method, and theory codes exceeds the number of articles in the sample.

\section{Table 1}

Figure 1

The software's query features allow nearly unlimited search and discovery of relations among coded data. These queries form the analyses that follow in this study.

Measures of correspondence. The study measures correspondence between research and practice to capture different dynamics of information exchange between the realms of inquiry. The study defines differences in changes and levels of topic frequency as measures of correspondence. Research and practice topic frequencies are scaled by the total number of research or practice topics to control for the relative sizes of the two outlets. The study examines contemporaneous and lagged differences, as the data

\footnotetext{
${ }^{4}$ Malina and Selto [2001] describe this qualitative method in more detail.
} 
permit, for evidence of topic correspondence. Furthermore, the study investigates whether research topic frequency leads or lags practice.

Validity issues. One researcher coded all of the practice article abstracts in the database and a 5 percent random sample of the research abstracts. Another researcher coded all of the research abstracts and a 5 percent random sample of the practice abstracts. Inter-rater reliability of the overlapped coding was $95 \%$, measured by the proportion of coding agreements divided by the sum of agreements plus disagreements from the 5 percent random samples of articles in the research and practice databases. ${ }^{5}$ Because the measured inter-rater reliability is well within the norms for this type of qualitative research (i.e., greater than 80 percent) and because hypothesis testing or model building is not the primary objective of the study, the researchers did not revise the database to achieve consensus coding.

Aggregate analysis. Figure 2 shows the most aggregated level of analysis used in this study, which reflects the levels of research and practice frequencies of major topics. The three most frequent practice topics in figure 2 are (1) software, (2) management control, and (3) cost management. ${ }^{6}$

\section{Figure 2}

The Institute of Management Accountants (IMA) analyzed the practice of management accounting $[1997,2000]$ in part by asking respondents to identify critical work activities that are currently important and that are expected to increase in the future. The IMA reports that 21 percent of respondents identified computer systems and operations as one of the five most critical current work activities and 51 percent believe that this work activity will increase in importance in the future. Eighteen percent of respondents in the IMA practice analysis state that control of customer and product profitability is one of the most critical work activities; however, 59 percent of respondents believe that this is one of the work activities that will increase in importance in the future. The topic code "management control" includes sub-topics related to control of customers, customer profitability, quality, and new products. Finally, the IMA practice analysis found that 25 percent of respondents stated that "financial and economic analysis" was one of the most critical current work activities. Forty-two percent believed it would be more important in the future. The topic code "cost management" includes cost reduction, efficiency, activity-based management, and activity-based costing.

\footnotetext{
${ }^{5}$ Ninety-seven article abstracts (containing 126 supercodes) were dual coded by both researchers. Five articles contained multiple codes of which one super code in each article was not in agreement between researchers.

${ }^{6}$ The term "software" reflects selection, implementation, and management of software systems and the hardware to run them. "Cost management" refers to activities to create more value at lower cost and is distinguished from cost accounting, which measures costs.
} 
The aggregate results of applying this study's coding scheme to the practice literature are consistent with those of the IMA's practice analysis. The similarity of aggregate results from this study and the IMA's survey of practice support the validity of this study's coding scheme.

\section{Analysis of Topic Frequency Changes}

The qualitative software enables several types of "drill-down" analyses at major topic and subtopic levels. These analyses support the statistical and graphical analyses that follow. The basic analysis in Figure 2 guides all subsequent analyses. Relatively large differences in overall topic frequency are evident in this graph (e.g., budgeting, management control, performance measurement, and software), but more detailed analyses are used to identify less researched questions.

Associated changes in topics can be evidence of information exchange between research and practice. If researchers and practitioners are communicating about topics of mutual interest, one expects changes in topic frequency (contemporaneous or lagged) to be closely associated over time. Creating tables of topic frequencies for each year (by disaggregating the data underlying figure 2) supports an investigation of contemporaneous and lagged topic changes. The study finds no significant correlations $(\alpha=0.10)$ between changes in research and practice topic-frequencies that are either contemporaneous or lagged (plus or minus one year). Analysis of topic levels finds numerous opportunities for communication and exchange of findings between research and practice.

\section{Analysis of Topic Frequency Levels}

\section{Contemporaneous Frequency Levels}

Analysis of contemporaneous levels shows some evidence of topic correspondence. For example, a glance at Figure 2 shows visual correspondence. The contemporaneous overall correlation coefficient, which equals 0.45 , is highly significant $(\mathrm{p}<0.0001)$. We obtain similar overall results for individual years $(0.3<\mathrm{R}<0.6)$. Note that these annual correlations do not reflect a monotonic increase of correspondence over time. However, the data show that modest contemporaneous correspondence of research and practice topics exists.

\section{Lagged Frequency Levels}

Analysis of lagged topic frequency levels also shows similar correspondence. Examining whether practice leads research by 1 year yields an overall correlation coefficient (rounded) of 0.4 ( $\mathrm{p}<0.0001$ ). Annual correlation coefficients range between 0.3 and 0.5 for each lagged year. These are also highly significant and reflect a " $U$ " shaped pattern over time. Testing if research leads practice by 1 year generates an overall correlation coefficient of 0.5 and $0.3<\mathrm{R}<0.6$ for each lagged year (all highly 
significant). Furthermore, coefficients of research leading practice increase monotonically, suggesting increasing correspondence over time.

Thus, this study finds mixed evidence of correspondence between research and practice: Analysis of lagged topic frequency levels suggests increasing correspondence, but changes in topic frequency show no evidence. This suggests that evidence of correspondence may reflect coincidence rather than active or causal exchange of information between researchers and professionals. To resolve this ambiguity we look more closely at topic levels.

\section{Analysis of Correspondence of Topic Levels}

One can observe many instances in Figure 2 where topic frequency differences are less than 5 percent, which indicate high correspondence between research and practice. Most of these topics apparently are of relatively minor interest to both researchers and professionals (i.e., total frequency of either practice or research is less than 5 percent). While these low frequency topics may represent emerging areas for both realms, we focus here on topics that also have at least 5 percent $^{7}$ of the total article coverage in either practice or research. The only major topic meeting these criteria is "cost management."

\section{Cost Management}

Topics coded as cost management comprise approximately 14 percent of all practice topics and 13 percent of research topics, leaving only a 1 percent difference. Is this high correspondence the result of coincidence or cross-fertilization? To answer that question, one can drill down into the database to contrast cost-management subtopics. The result of this analysis is shown in figure 3 .

\section{Figure 3}

A close look at figure 3 indicates that general cost-management correspondence is questionable. Benchmarking is the only subtopic with appreciable topic frequency and relatively high correspondence, comprising roughly 13 percent of practice and 9 percent of research subtopics. Examination of benchmarking-research articles shows they are evenly split between prescription and statistical analyses of the properties of benchmarks. There are, however, no research studies of the impacts of benchmarking. Practice articles are either prescriptions or self-reports of implementation or reports of organizational improvements attributed to benchmarking.

Benchmarking questions. Several benchmarking research questions seem obvious, including:

\footnotetext{
${ }^{7}$ The 5 percent cutoffs are arbitrary but retain the great majority of research and practice articles for study. Without some cutoff, the research would resemble an annotated bibliography of 2,000 articles. We do run the risk of ignoring particularly interesting but relatively unreported topics.
} 
"What are the costs and benefits of benchmarking at the process, service, or firm levels?" One should be able to measure costs of benchmarking activities, but, as is usually the case, benefits may be more elusive. Attributing improvements in processes to benchmarking may be more feasible than attempting to explain business unit or firm-level financial performance.

"What are the attributes of successful or unsuccessful design and implementation of benchmarking?" Addressing this question perhaps should follow the first unless one wants to proxy costs and benefits with user satisfaction measures.

Given that apparent correspondence at the cost-management subtopic level yielded new research questions, examination of other cost management subtopics also might bear fruit. For example, only three percent of research studies exist in the area of activity-based management (ABM) - a difference of nearly 8 percent - which seems surprising given this topic's high profile over the past decade, and no research on shared services - a difference of 6 percent. Several interesting research questions for these topics include:

Activity-based management questions. Several ABM research questions from practice are:

Does ABM lead to observable improvements in processes, products, services, and financial performance? Self-reports indicate that ABM delivers improvements, but one suspects that these self-reports are censored and most reports of failures are either not written or published. What are determinants of successful ABM efforts? Determinants may include communication, team structure, management style, and management support and involvement.

How can organizations successfully move from ABM pilot projects to wider deployment? Most ABM self-reports reflect results of limited pilot projects. Does implementation of ABM spread? How?

Shared services questions. The topic of shared services refers to centers that provide business services, such as finance, human resources and legal. This service center would contract with business units, much as an outsourced-service provider would. Questions include:

What are the efficiencies of locating business services in shared service centers? Cost savings are part of the equation, but effects on usage and quality of service also are important. This leads to related considerations of transfer pricing and performance evaluation.

Is $A B M$ necessary to justify shared or outsourced services? Is ABM the tool to use to identify opportunities, communicate rationales, and ease transition to shared service centers?

What are the organizational impediments and arguments for shared services versus distributed or outsourced services? Alternative organizational structures and contracting may have inertia and power considerations as well as economic. 
Relatively more research than practice exists in several cost-management areas, including activitybased costing $(\mathrm{ABC})$ - a difference of 29 percent - and strategy - a difference of 5 percent. However, perhaps surprisingly, numerous practice-oriented questions remain relatively un-researched.

Activity-based costing questions. Practice-oriented research questions in this area include:

What is the optimal complexity of $A B C$ systems? Costs and benefits of complexity include design and maintenance costs, cognitive complexity, and value of finer information. Standard costing systems are notoriously expensive to maintain; are ABC systems even more so? Is it possible to prescribe optimal complexity or describe the complexity of apparently successful ABC systems? Are different levels of complexity appropriate for different purposes (e.g., product costing versus strategic decision making)?

Are objectivity and precision of measurement incompatible with efficient ABC systems? What are the information quality tradeoffs? This has added importance for $\mathrm{ABC}$ systems that are intended to serve multiple purposes, including reporting, costing, decision making, and performance measurement.

Strategy questions. Most research studies use measures of strategy as independent variables to explain performance or other organizational outcomes. Practical concerns related to strategy include: What are appropriate ratios or indicators to measure whether an organization is meeting its strategic goals, which may be heavily marketing and customer oriented? Are these indicators financial, non-financial, or qualitative? Numerous practice articles argue that strategic management is possible only with the "right indicators." But what are they? How are they used? With what impact?

Is the balanced scorecard an appropriate tool for performance evaluation, as well as for strategic planning and communication? The BSC is offered as a superior strategic planning and communication tool. Many organizations are inclined to also use the BSC (or similar, complex performance measurement models) as the basis for performance evaluations. What complications does this extension add? With what effects?

Are scenarios from financial planning models effective tools for strategic management? Financial modeling is an important part of financial and cost management. Do strategic planners need or use scenarios from these models? Why or why not? With what effects?

Relatively less research than practice exists in the area of cost reduction/efficiency - a difference of $22 \%$. Practice coverage of this topic is fairly uniform over the 5-year study period. Although research coverage peaked in 1998, some coverage continued into 2000. 
Cost reduction/efficiency questions. Perhaps accounting researchers consider issues of cost reduction and efficiency to be too basic for research inquiry. Practice is concerned with interesting developments that could benefit from a research perspective. Sample questions from practice include:

"What is the efficiency of spending to increase customer satisfaction?" Though a number of researchers have addressed this issue (e.g., tests of statistical relations between customer satisfaction and profitability), it is of continuing interest to practice, particularly at the level of developing guidelines for efficient management of customer relations.

"What are the effects of IT and organizational changes on efficiency?" There appears to be no research that addresses this type of question. Relevant contexts abound, including telecommuting, outsourcing, and internal support services.

"What are the effects of IT on total costs and productivity?" The information systems literature commonly focuses on measuring IT-user satisfaction while larger issues of efficiency remain under-researched. Application contexts include finance, human resources, procurement, payables, travel, payroll, customer service.

Perhaps surprisingly, observed major-topic correspondence yields much evidence of low correspondence and many interesting, less researched questions. Even when researchers and professionals address similar topics, they focus on different questions. An examination of topics with more obvious low correspondence yields even more research opportunities.

\section{Analysis of Low Correspondence of Topic Levels}

Low correspondence is defined as topic-frequency differences in excess of 5 percent. These differences include topic areas where research exceeds practice: budgeting (6.5 percent difference), management control (14 percent difference), and performance measurement (16 percent difference).

The data also reveals major topic areas where practice exceeds research, including business processes (5 percent difference), internal control (6 percent difference), electronic business ( 7 percent difference), and software (19 percent difference). Perhaps these are areas of particularly abundant new research opportunities. ${ }^{8}$ The study presents analysis of low correspondence where budgeting research exceeds practice and where practice writings on electronic business issues exceed research. The appendix contains similarly identified research questions from each of the other topic areas.

\section{Budgeting (Research $>$ Practice)}

\footnotetext{
${ }^{8}$ In concept, one might prefer to separate practice descriptions of emerging problems from advocacy for preferred solutions._Some also might argue that research naturally investigates different topics than practice. This study regards all differences as opportunities for interesting research.
} 
Budgeting is a venerable management accounting research topic, and one might think that there are few un-researched questions remaining. If so, have researchers not communicated results to practice, or are they pursuing less practice-oriented topics? As before, one can drill down into the data to the budgeting sub-topic level to assess budgeting correspondence. Figure 4 presents topic frequencies of budgeting sub-topic coverage.

Figure 4

The data contain no practice publications in topic areas of budget slack (Difference $=10 \%$ ) and budget variances $($ Difference $=16 \%$ ). More research than practice exists in the areas of capital budgeting $($ Difference $=11 \%)$ and participative budgeting (Difference $=21 \%)$. These topics appear to be of little current, practical interest, but they continue to attract research efforts, perhaps because of tradition and the interesting theoretical issues they present. It also is possible that researchers' long concern with budgetary slack still leads practice. For example, excess budget slack conceivably might be included with other dysfunctional actions designed to manipulate reported performance and targeted for elimination by financial reforms. Conversely, the data contain no research in topic areas of activity-based budgeting (Difference $=10 \%$ ) and planning $\&$ forecasting (Difference $=65 \%$ ). The latter area, planning and forecasting, has a large topic difference and has grown in practice coverage each year of the study period.

Planning and forecasting questions. Just a few questions from practice include:

"What are the determinants of effective planning and forecasting?" Effective planning and forecasting can be defined as (1) accurate, timely, and flexible problem identification, (2) communication, and (3) leading to desired performance. Researchers may find environmental, organizational, human capital, and technological antecedents of effective planning and forecasting methods and practices. Whether these are situational or general conditions would be of considerable interest.

“What exogenous factors affect sales and cost forecasting?” This includes consideration of the related question, "What is a parsimonious model?” Nearly every management accounting text states that sales forecasting is a difficult task. Likewise, cost forecasting can be difficult because of the irrelevancy or incompleteness of historical data. Yet both types of forecasting are critical to building useful financial models and making informed business decisions.

“What are effects of merging BSC or ABC with planning \& forecasting?" $\mathrm{ABC}$ and the balanced scorecard represent current recommendations for cost and performance measurement. However, the research literature has not extensively considered the uses or impacts of these tools, which may be particularly valuable for planning and forecasting. 
"What are the roles of IT \& decision-support systems in improving planning \& forecasting?"

Most large organizations use sophisticated database systems, and accessing and using information can be facilitated by intelligent interfaces and decision support systems. Yet we know little about the theoretical and observed impacts of these tools in general and almost nothing about their effects on planning and forecasting.

\section{Electronic Business (Practice >> Research)}

Topics coded as electronic business comprise approximately 7 percent of all practice topics, yet there is no management accounting research in this area. To determine if perhaps researchers are investigating electronic business issues and publishing in journals outside of mainstream management accounting journals, we also reviewed Information Systems research journals (MISQ, JMIS, JIS) and found no evidence that research in this area is being conducted in these journals. Due to the increasing emphasis of the role that technology plays in business in today's competitive, global and fast-changing world, a 7 percent difference in this topic with no research seems surprising. Surely, electronic business is a research topic guaranteed to generate practical interest.

\section{Figure 5}

An in-depth look at Figure 5 shows that there are several main categories of sub-topics within electronic business. Approximately 31 percent of electronic business topics are articles of a general nature, 25 percent are related directly to issues on electronic commerce, 22 percent are concerned with the internet and websites, 16 percent are about processing transactions electronically, and the remaining 6 percent focus on the use of XML (extensible markup language).

Electronic business (general) questions. General electronic business issues center on the reengineering of business processes and business models to take advantage of electronic means of transacting business and creating efficiencies and enhanced performance for the firm. This generates opportunities for research questions related to the successful start-up of e-ventures, the changes in underlying business models, and the use of technology to reduce costs.

"What are appropriate management controls, internal controls, and performance measures for E-business ventures?" This includes the related question, "Do they differ from conventional business?" Doing business in the "New Economy" has impacted the underlying business model of most firms thus impacting the design of the firm's management control system, internal control environment, and performance measurement system.

"What technologies drive enhanced productivity and efficiencies in the firm?” Firms must be able to perform cost/benefit analysis weighing the potential benefits to be gained from employing new 
technologies against the cost of implementing that technology and reengineering the business process. Two related questions are "What is the optimal capital budgeting model for electronic business?" and "Which business processes lend themselves to a reengineering process that would result in increased efficiencies and reduced costs?”

Electronic commerce questions. Practitioners appear to be primarily concerned with the management of costs in the electronic commerce space and the proper tracking and measurement of performance. These concerns lead to several promising research questions:

What is the optimal amount for web-retailers to spend on customer acquisition costs? The prevailing business model among e-tailers was to increase traffic on the website and worry about revenues later. But what is too much to pay to acquire a new customer? How do e-tailers know how much to spend on customer acquisition costs?

What performance metrics do firms need to track to effectively manage electronic customers and the integration of e-commerce with their current business model? How does a firm evaluate investments in e-commerce? What metrics are appropriate for measuring the performance of e-commerce initiatives? Not too long ago metrics focused on traffic, now firms are more focused on the generation of revenue. Identifying the appropriate drivers, outcome measures, and the timing and pattern of associations between the two are interesting areas for potential research.

How does electronic data interchange affect the management control system? Electronic commerce is changing traditional business practices in areas such as increased use of bar coding of transactions and inventory, and the use of electronic procurement. How do these new business practices impact the design of the MCS?

Internet and website questions. The internet both facilitates the timeliness, exchange, and availability of information. Practice is particularly concerned with the impact the internet has on the reporting and use of financial information.

What are the characteristics of an effective website? Firms are implementing intranets and websites for communication of information within the firm. This question includes a related question: "What characteristics of websites facilitate effective exchange of accounting information between the firm and its investors? Or between users and/or business units within the firm?"

What is the impact of displaying financial information on a web site on the firm's business risk? Firms now distribute financial accounting information on company websites. How does this practice impact the firm's internal control environment? How does it impact a company's risk of litigation? Are there controls that the firm can implement to reduce the associated risk?

Electronic processing. The processing of accounting transactions can be a tedious and timeconsuming task. Electronic processing of transactions can create efficiencies within organizations. 
Questions of interest are primarily related to how electronic processing can improve firm performance and efficiencies.

How should accounting workflows and transaction processing be reengineered to take advantage of electronic processing? Firms need to know how to integrate an environment that traditionally generates lots of paper and incorporates many formal controls with an electronic processing environment that may not generate any paper and dispenses with some of the traditional controls.

What is the impact of electronic processing on the firm's control environment? With the potential for increased efficiencies arising from the reduction of traditional paper documents, there may not be a paper trail left to substantiate and document transactions. What is the impact on internal control? Is a paperless environment cost effective?

Extensible markup language. Extensible markup language (XML) (also, extensible business reporting language, XBRL, and extensible financial reporting markup language, XFRML) is fast becoming the language of accounting. XML is used for a multitude of purposes including reporting accounting information to investors via the firm's website, uploading of SEC files and so forth. This leads to the question:

How do accountants successfully use extensible markup language (XML) to facilitate the exchange and communication of accounting information?

\section{Opportunities for Publication}

This section of the study addresses designing research for publishability. Because the major portion of the study has focused on identifying new research questions, it seems only prudent to anticipate the opportunities to publish this novel research. It is one thing to recommend that researchers take risks and tackle new research questions, but it might be quite another to get these efforts published in quality research journals. The analysis that follows finds that some research journals, which published management accounting articles during the period of study, have specialized but others have been more general. Certainly, publication history might be an imperfect predictor of future publications opportunities, but a Bayesian might condition estimates of publication probability with priors based on history. Prudence (or a strategic approach to conducting research) also suggests that researchers conceive and design their efforts to meet target journals' revealed preferences.

The study next analyzes the management accounting research database for topic coverage by major journal. The study also analyzes each journal's past publication practices regarding underlying theory, sources of data, and methods of analysis. This analysis is not intended to be a cookbook, but rather it is intended as realistic guidance based on historical evidence. Figure 6 displays coverage of major management accounting topics by journal. Figure 7 shows theories used in management accounting 
articles by journal. Similarly, figure 8 shows sources of data by journal. Finally, figure 9 shows methods of analysis by journal.

Figures 6, 7, 8, and 9

\section{Topic coverage}

Figure 6 shows some evidence of journal specialization by topic, although all the research journals have published at least some articles addressing these topics. For example, management control topics have appeared most often in AOS and MAR, both UK-based journals. Performance measurement issues have appeared most often in the North American journals, JAR, CAR, TAR, and JAE, and these journals also publish management control articles. This concentration may reflect editorial policies or results of years of migration of topics. Apart from concentration of performance measurement and management control, it appears that all the surveyed journals are open to publishing various management accounting topics.

\section{Theories}

Figure 7 shows some strong evidence of theory specialization by journals. For example, virtually the only theories used in management accounting articles published in JAR, etc. are economic in nature (agency or microeconomic theories). This is true also for management accounting articles published in predominantly management journals, SMJ, etc. Nearly the only outlets for papers using contingency theory are the UK journals, AOS and MAR. These journals plus AIMA and JMAR appear to be the broadest in using alternative theories.

\section{Methods of analysis}

As shown in figure 8, articles in JAR, etc. tend to use either analytical or statistical methods, but almost never use qualitative analyses. On the other hand, management accounting articles in other journals rarely use analytical methods, though they often use statistical methods. For example, articles in AIMA, AOS, and JMAR most often use statistical methods. Qualitative analysis appears mostly in the UK journals, AOS and MAR, followed by AIMA and JMAR.

\section{Sources of data}

Figure 9 shows specialization by journals in their uses of alternative data sources. JAR, etc. articles predominantly use archival data, though data from laboratory experiments also appear in JAR, etc. Field study and survey data appear most often in AOS and MAR, the UK journals. AIMA appears to be the most balanced in its data sources. JMAR, though a small player, publishes papers with a wide range of data, as does MAR and, to a lesser degree, AOS.

\section{Conclusions about publication opportunities}


Authors want to place their work in the most prestigious journals (a designation that varies across individuals and universities) and also want to receive competent reviews of their work. Thus it seems sensible (or perhaps explicitly strategic) to design research for publishability in desired outlets. As a practical matter, this strategic design perspective may lead researchers, who themselves specialize in theories and methods, to design practice-oriented management accounting research for specific journals. Historical evidence indicates that all surveyed journals may be open to new topics. Although several journals seem open to alternative theories and methods (AIMA, JMAR, MAR, AOS), the major North American journals have been more specialized. This may reflect normative values and practical difficulty of building and maintaining competent editorial and review boards. Thus, if one wants to pursue a new topic in research aimed at JAR, etc., for example, one perhaps should use a theory, source of data, and method that these journals have customarily published.

\section{Conclusion}

There is no shortage of interesting, potentially influential management accounting research questions. From an analysis of published research and practice articles, this study has identified many more than could be reported here. Even where research and practice topics appear to correspond, considerable divergence in questions exists. Identified research questions offer opportunities for ALL persuasions of accounting researchers. Synergies between management accounting and accounting information systems seem particularly obvious and should not be ignored. Furthermore, research methods mastered by financial accountants and auditors can be applied to management accounting research questions.

Even with efforts to design practice-oriented management accounting research for publishability, challenges to broader participation and publication might remain. Some of the challenges to publishing this type of management accounting research might include lack of institutional knowledge of authors, reviewers, and editors. To be credible, authors must gain relevant knowledge to complement their research method skills. For example, research on management control of information technology and strategic planning should be preceded by knowledge of the three domains, in theory and practice. Furthermore, editors and reviewers who want to support publication of practice-oriented research should be both knowledgeable of practice and open minded, particularly with regard to less objective sources of data. However, it does not seem necessary or desirable to lower the bar on theory or methods of analysis to promote more innovative research. In summary, we hope that this paper encourages management accounting researchers to take on the challenges of investigating interesting, innovative questions oriented to today's business world and practice of management accounting. 
Table 1

\title{
Article Database Codes
}

\author{
ARTICLE \\ article-ABSTRACT \\ article-AUTHOR(S) \\ article-DESCRIPTORS \\ article-journal-A\&F \\ article-journal-AIMA \\ article-journal-AMJ \\ article-journal-AOS \\ article-journal-CAR \\ article-journal-JAAF \\ article-journal-JAE \\ article-journal-JAR \\ article-journal-JMAR \\ article-journal-MAR \\ article-journal-RAS \\ article-journal-SMJ \\ article-journal-TAR \\ article-TITLE \\ article-VOLUME \& PAGES \\ article-YEAR \\ article-year-1996 \\ article-year-1997 \\ article-year-1998 \\ article-year-1999 \\ article-year-2000 \\ buddgeting-soc psych \\ budgeting-agency \\ budgeting-contingency \\ budgeting-econ-other \\ budgeting-jdm \\ budgeting-org change \\ budgeting-soc justice \\ budgeting-systems \\ GEOGRAPHY \\ geography-ANZ \\ geography-ASIA \\ geography-EUROPE \\ geography-INTERNATIONAL \\ geography-LATIN AMERICA \\ geography-NORTH AMERICA \\ METHOD \\ method-ANALYSIS \\ method-analysis-analytical \\ method-analysis-qualitative \\ method-analysis-statistical \\ method-ARCHIVAL \\ method-EXPERIMENT
}




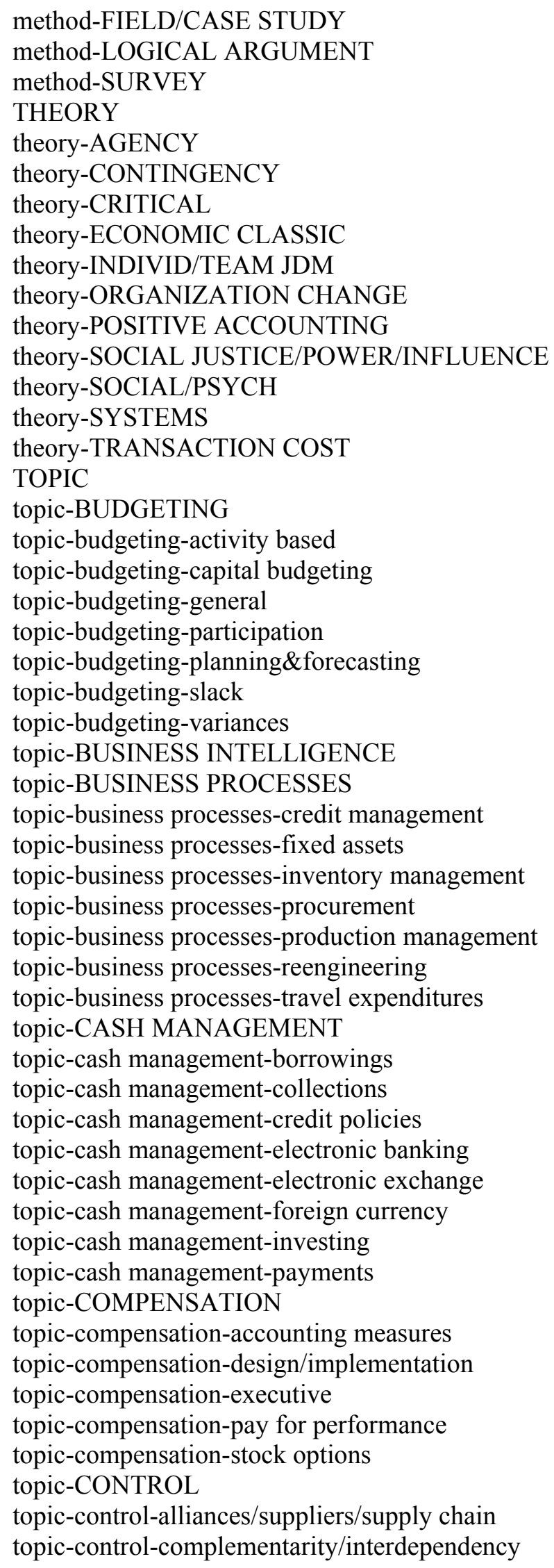


topic-control-cost of capital

topic-control-customers/customer profitabilty

topic-control-environmental

topic-control-information/information technology

topic-control-intangibles

topic-control-international/culture

topic-control-JIT/flexibility/time

topic-control-org change

topic-control-quality

topic-control-R\&D/new product develop

topic-control-risk

topic-control-smart cards/purchasing cards

topic-control-strategy

topic-control-structure

topic-control-system

topic-COST ACCOUNTING

topic-cost accounting-environmental

topic-cost accounting-general

topic-cost accounting-standards

topic-cost accounting-throughput

topic-COST MANAGEMENT

topic-cost management-ABC

topic-cost management-ABM

topic-cost management-benchmarking

topic-cost management-cost efficiency/reduction

topic-cost management-cost negotiation

topic-cost management-costing

topic-cost management-process mapping

topic-cost management-quality/productivity/tqm

topic-cost management-shared services

topic-cost management-strategy

topic-cost management-target costing

topic-cost management-theory of constraints/capacity

topic-ELECTRONIC

topic-electronic-business

topic-electronic-commerce

topic-electronic-intranet

topic-electronic-processing

topic-electronic-web sites

topic-electronic-xml/xbrl

topic-EXPERT SYSTEMS

topic-FINANCIAL ACCOUNTING

topic-financial reporting-accounting standards/SEC

topic-financial reporting-depreciation

topic-financial reporting-drill downs

topic-financial reporting-e reporting

topic-financial reporting-environmental

topic-financial reporting-general

topic-financial reporting-international

topic-financial reporting-open books

topic-financial reporting-realtime accounting 
topic-INTERNAL CONTROL

topic-internal control-controls

topic-internal control-corporate sentencing guidelines

topic-internal control-data security/computer fraud

topic-internal control-ethics

topic-internal control-fraud awareness/detection

topic-internal control-internal audit

topic-internal control-operational audits

topic-MANAGEMENT ACCOUNTING-practices

topic-OTHER

topic-OUTSOURCING DECISION

topic-PERFORMANCE MEASUREMENT

topic-performance measurement-balanced scorecard

topic-performance measurement-business process

topic-performance measurement-EVA/RI

topic-performance measurement-evaluation/appraisal

topic-performance measurement-group

topic-performance measurement-incentives

topic-performance measurement-individ

topic-performance measurement-manipulation

topic-performance measurement-nonfinancial

topic-performance measurement-productivity

topic-performance measurement-strategic

topic-performance measurement-system

topic-PRICING

topic-PROFITABILITY

topic-PROJECT MANAGEMENT

topic-RESEARCH METHODS

topic-SHAREHOLDER VALUE

topic-SOCIAL RESPONSIBILITY

topic-SOFTWARE

topic-software-ABC/product costing

topic-software-accounting technology (general)

topic-software-budgeting

topic-software-costing

topic-software-credit analysis

topic-software-data conversion

topic-software-database

topic-software-decision support

topic-software-document management

topic-software-erp

topic-software-fixed assets

topic-software-graphical accounting

topic-software-groupware

topic-software-human resources/payroll

topic-software-internet

topic-software-mindmaps

topic-software-modules

topic-software-operating system

topic-software-project accounting

topic-software-purchasing 


\author{
topic-software-reporting \\ topic-software-sales/C/M \\ topic-software-selection/accounting platforms/implementation \\ topic-software-spreadsheets \\ topic-software-t\&e \\ topic-software-warehousing/datamarts/intelligent agents \\ topic-software-workflow \\ topic-software-year2000 compliant \\ topic-TRANSFER PRICING \\ topic-VALUATION \\ topic-VALUE BASED MANAGEMENT \\ topic-VALUE CHAIN
}


Figure 1

Example of Coded Article Data

Fle Documents Quotations Godes Memos Networks Wews Extras Help

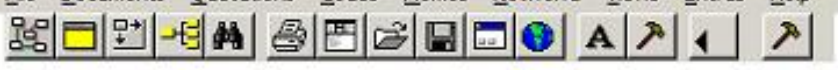

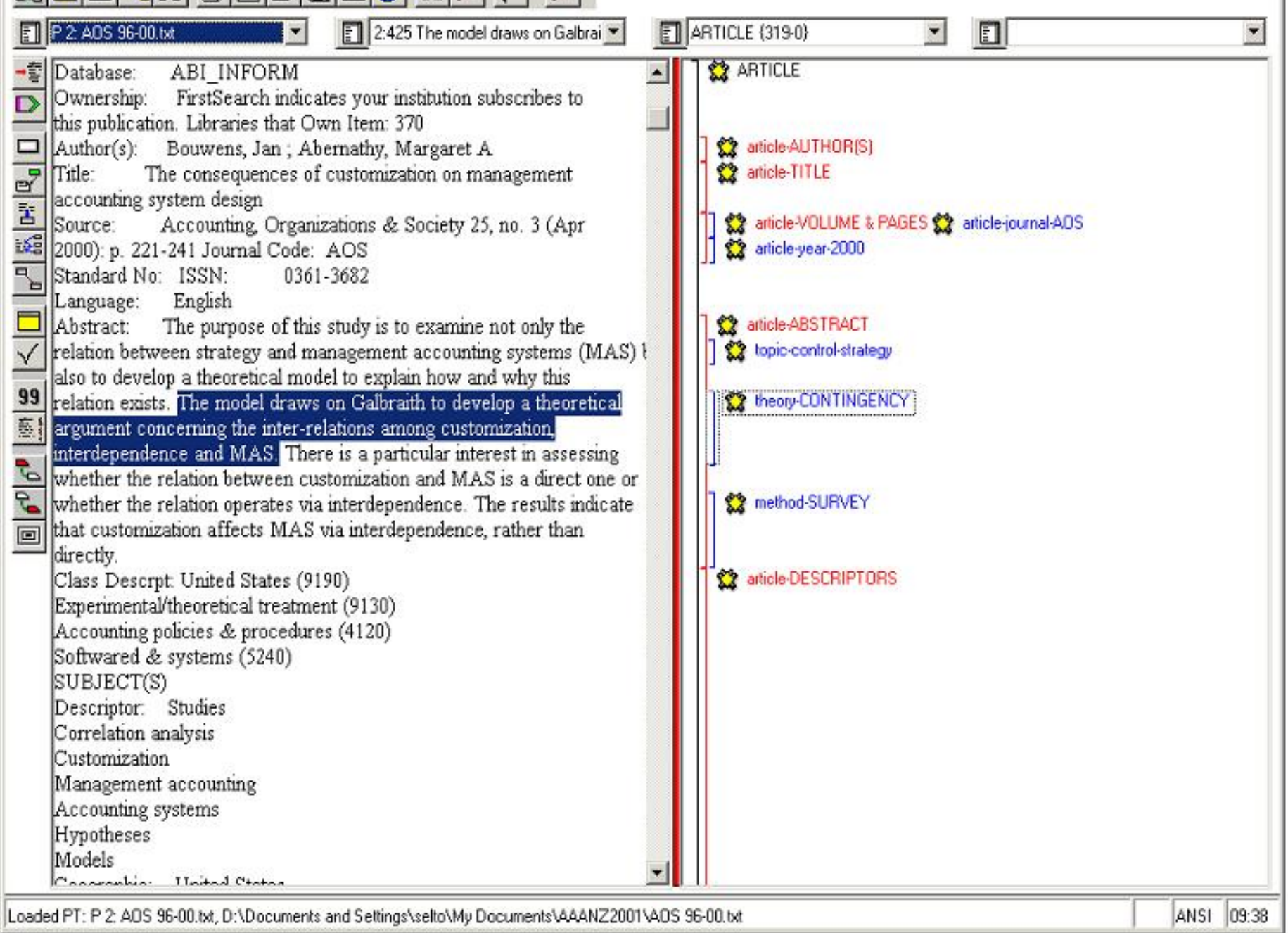


Figure 2

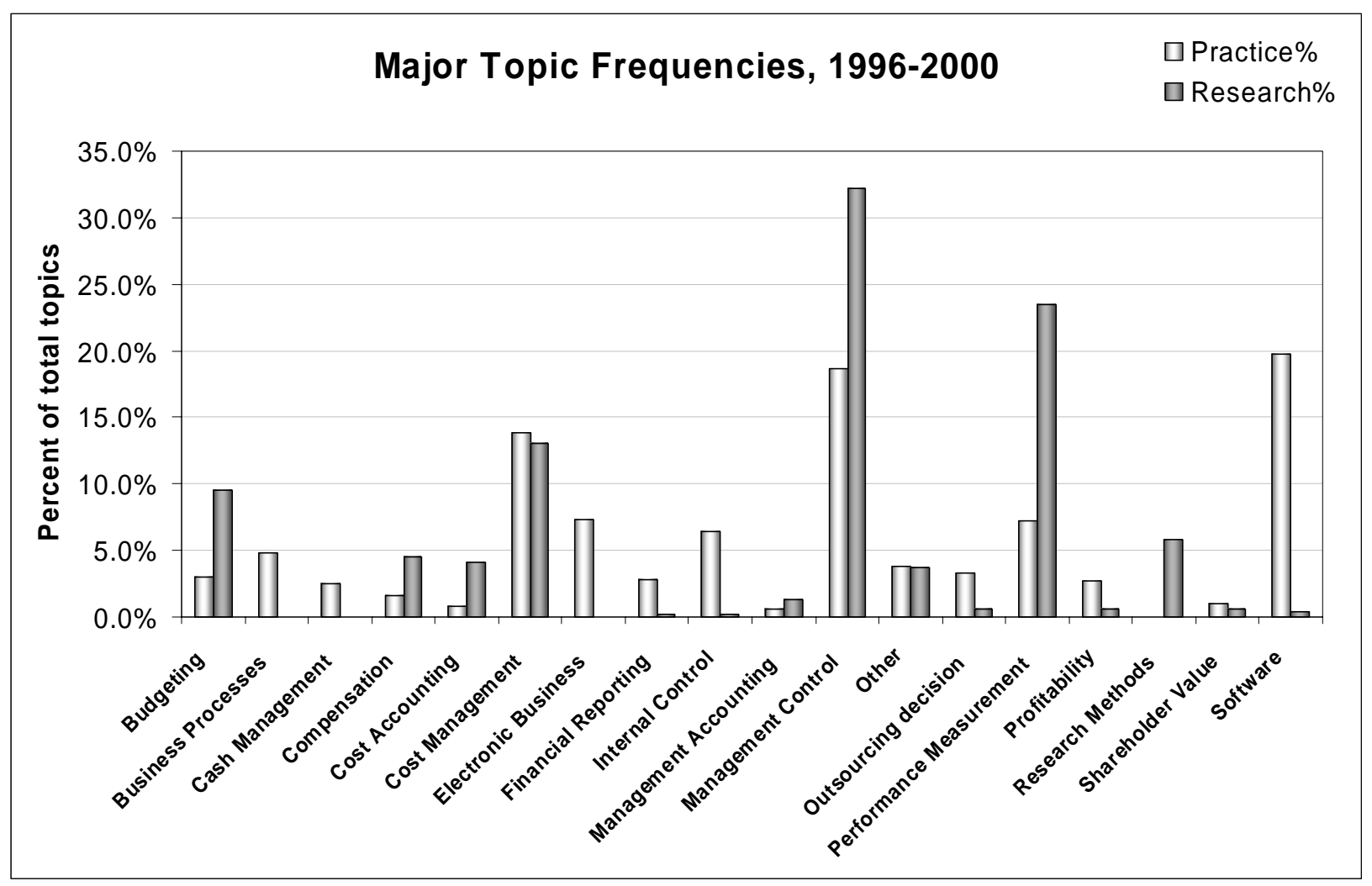


Figure 3

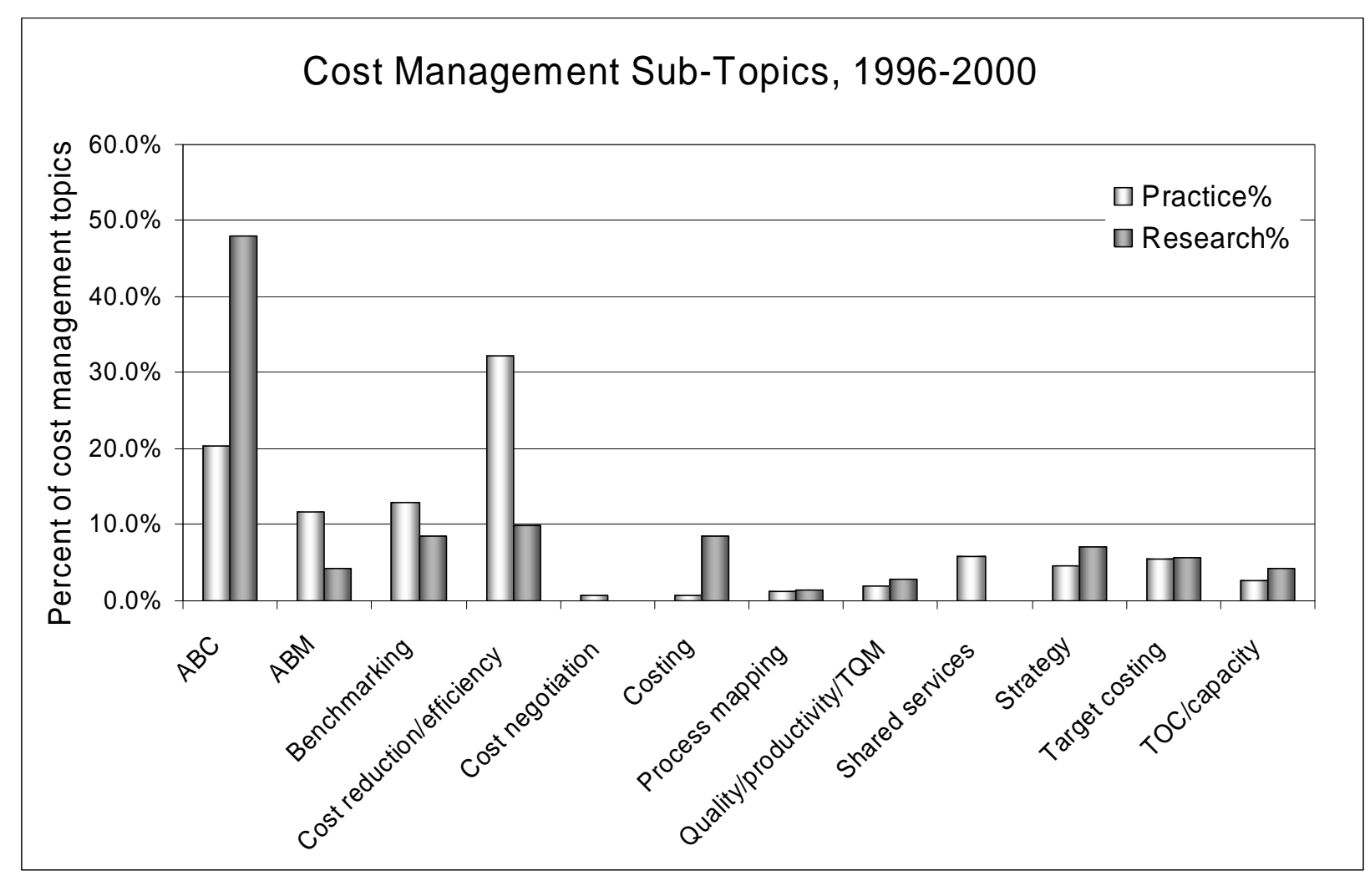


Figure 4

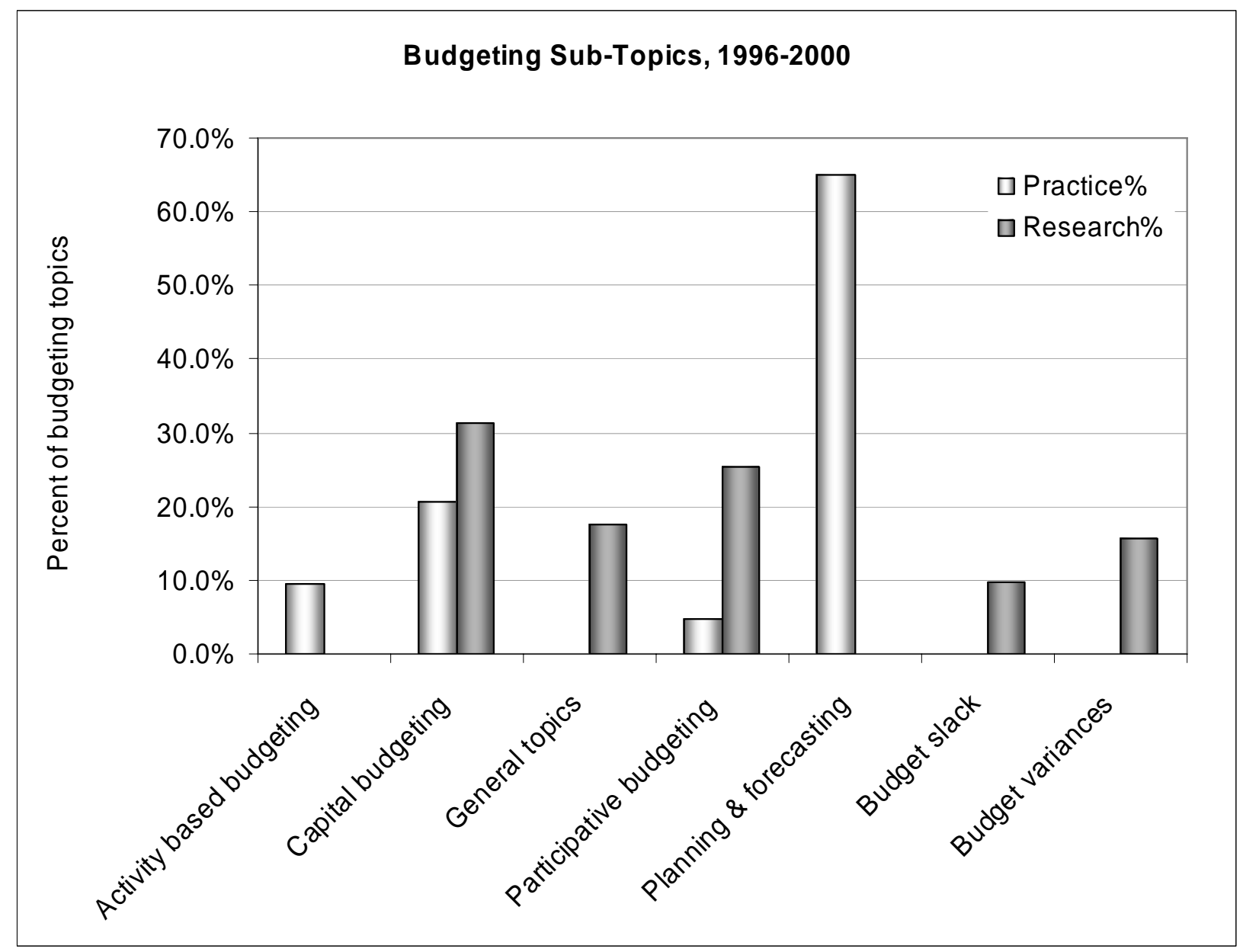


Figure 5

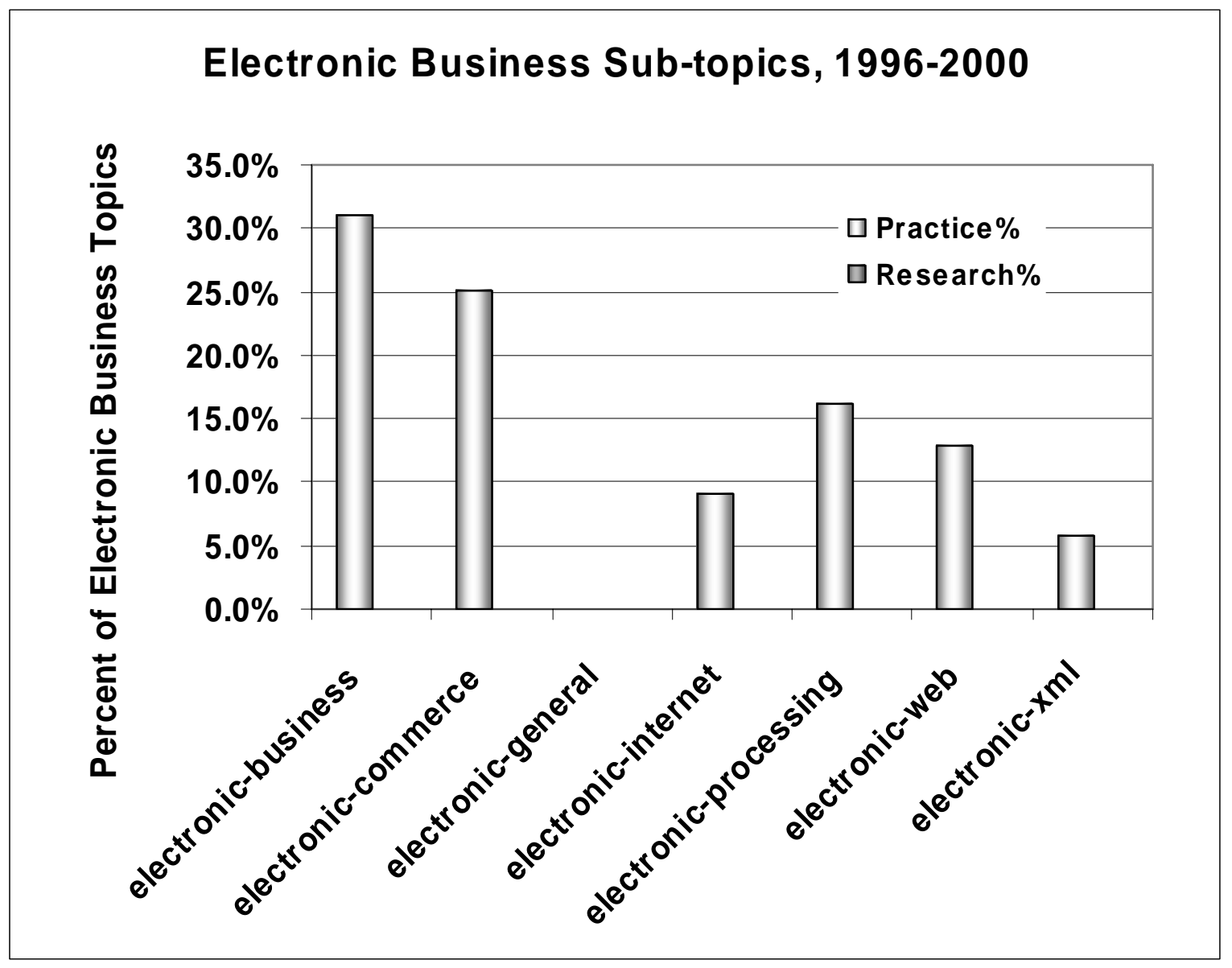


Figure 6

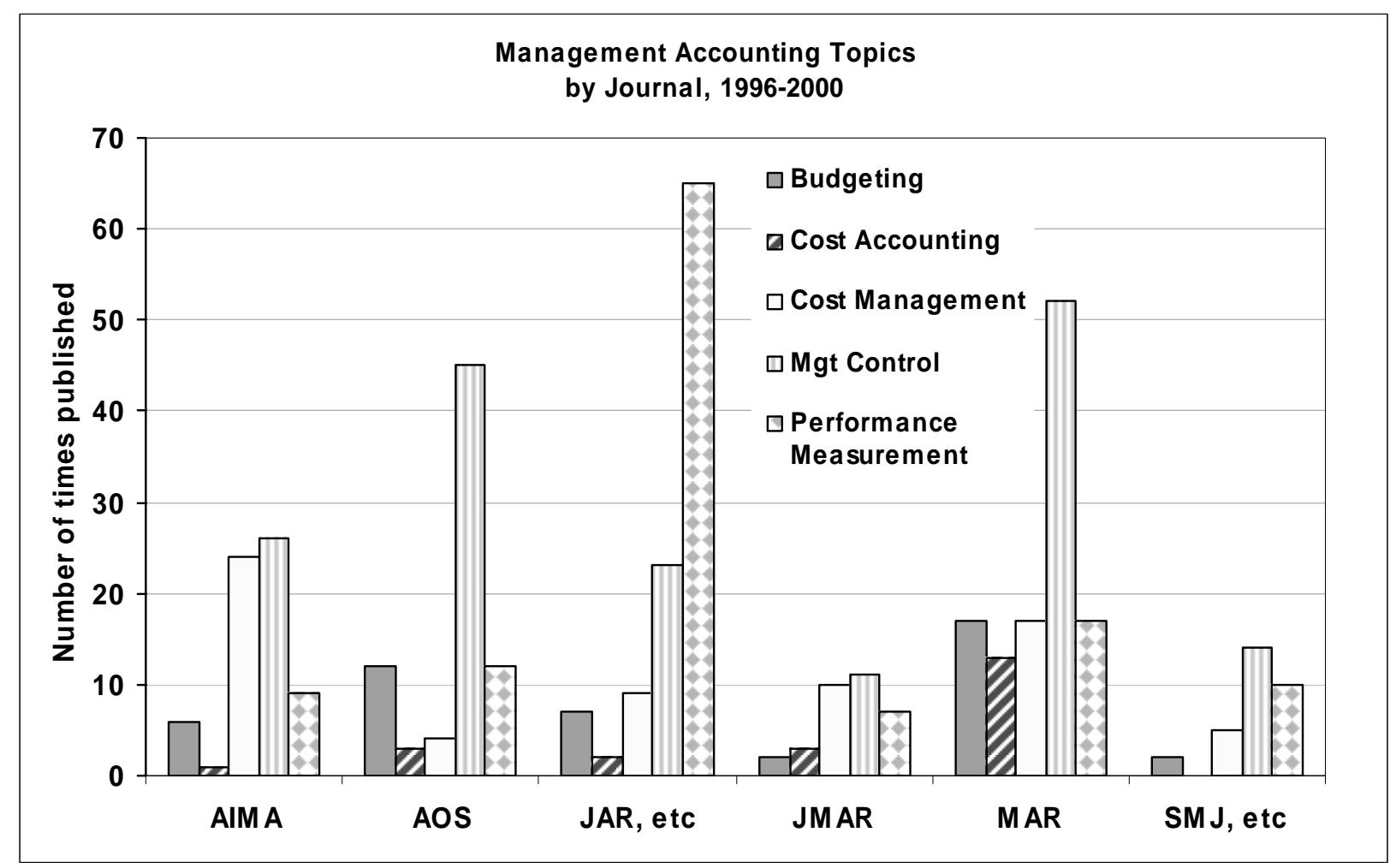


Figure 7

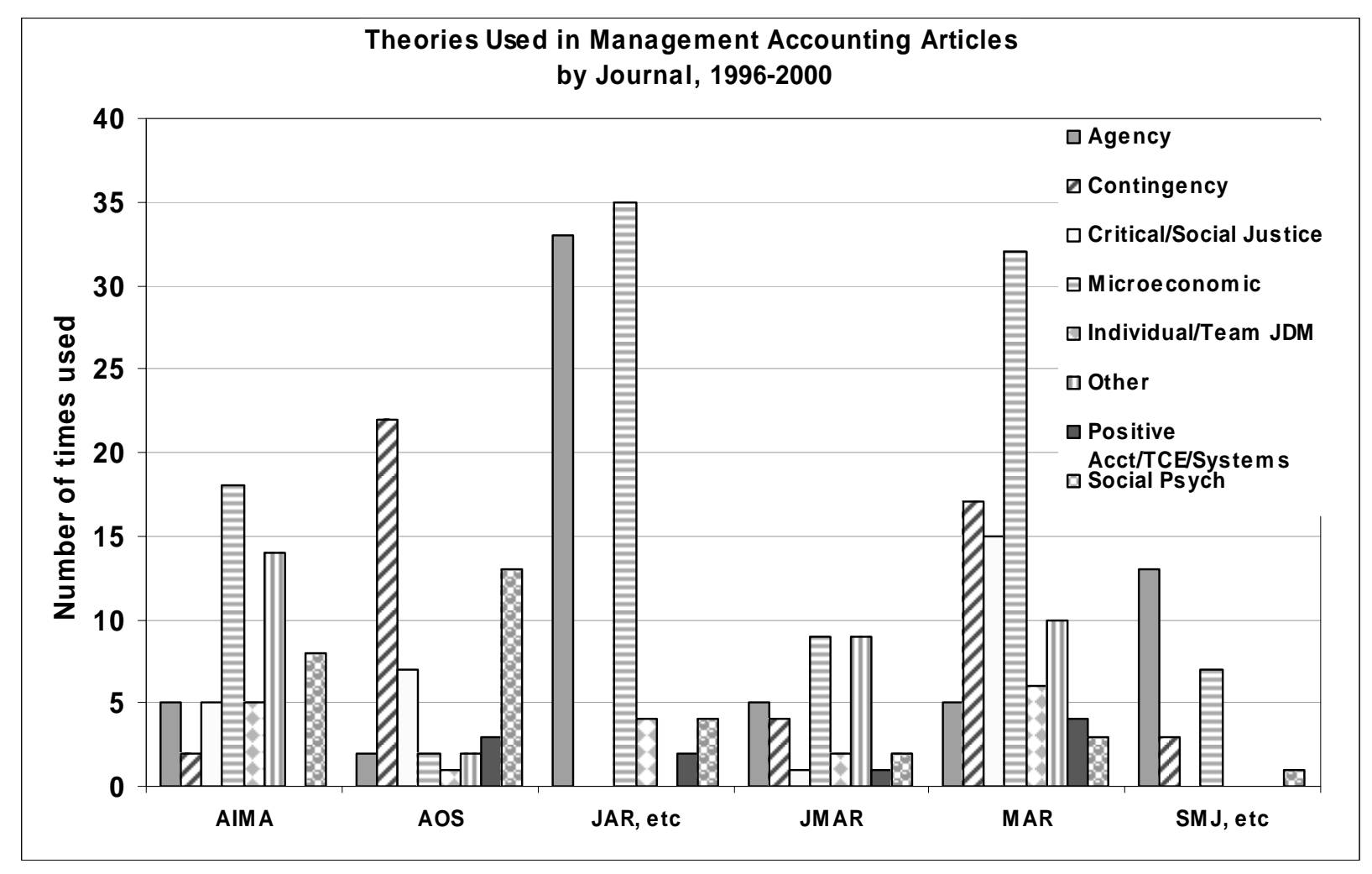


Figure 8

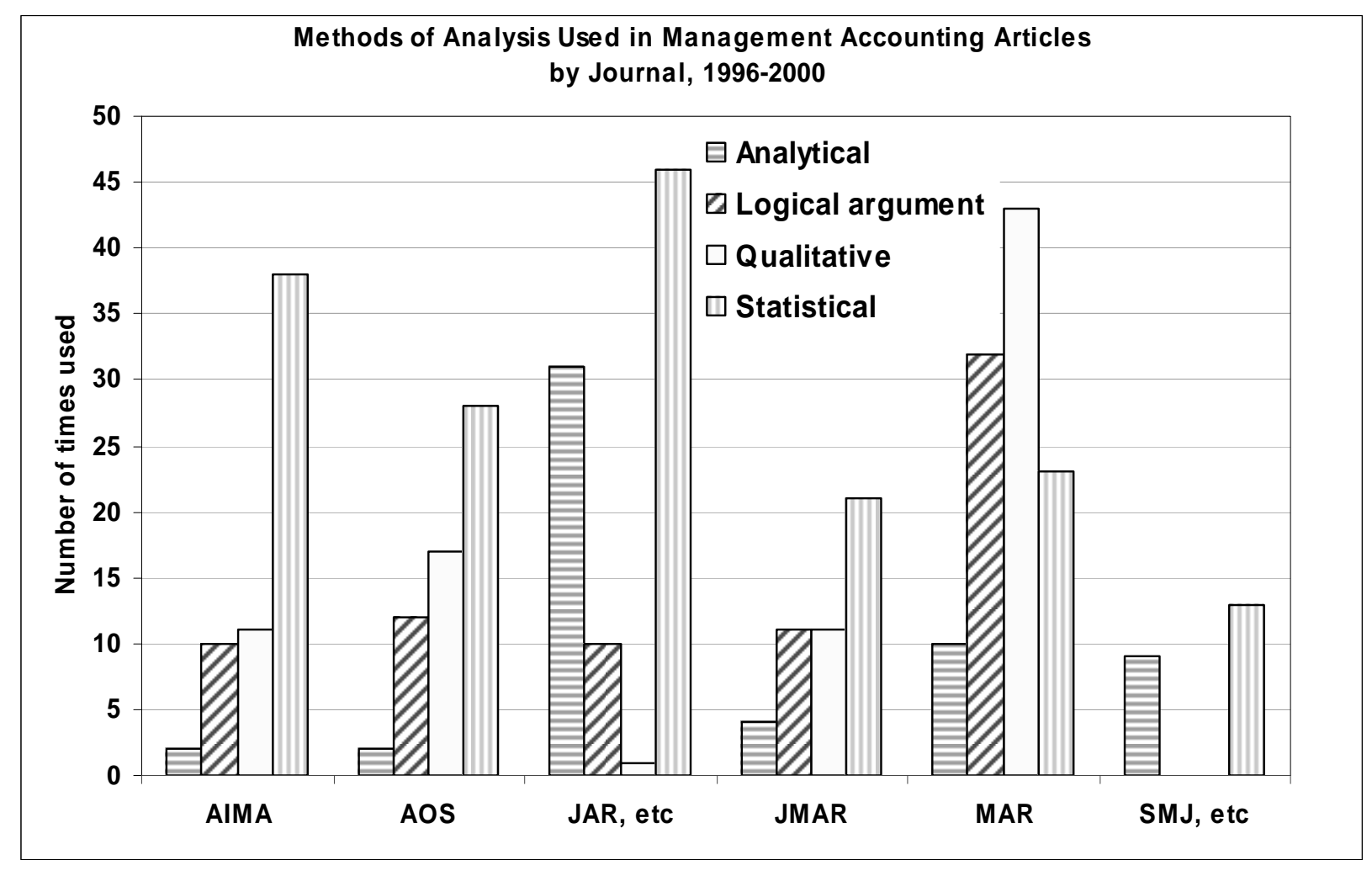


Figure 9

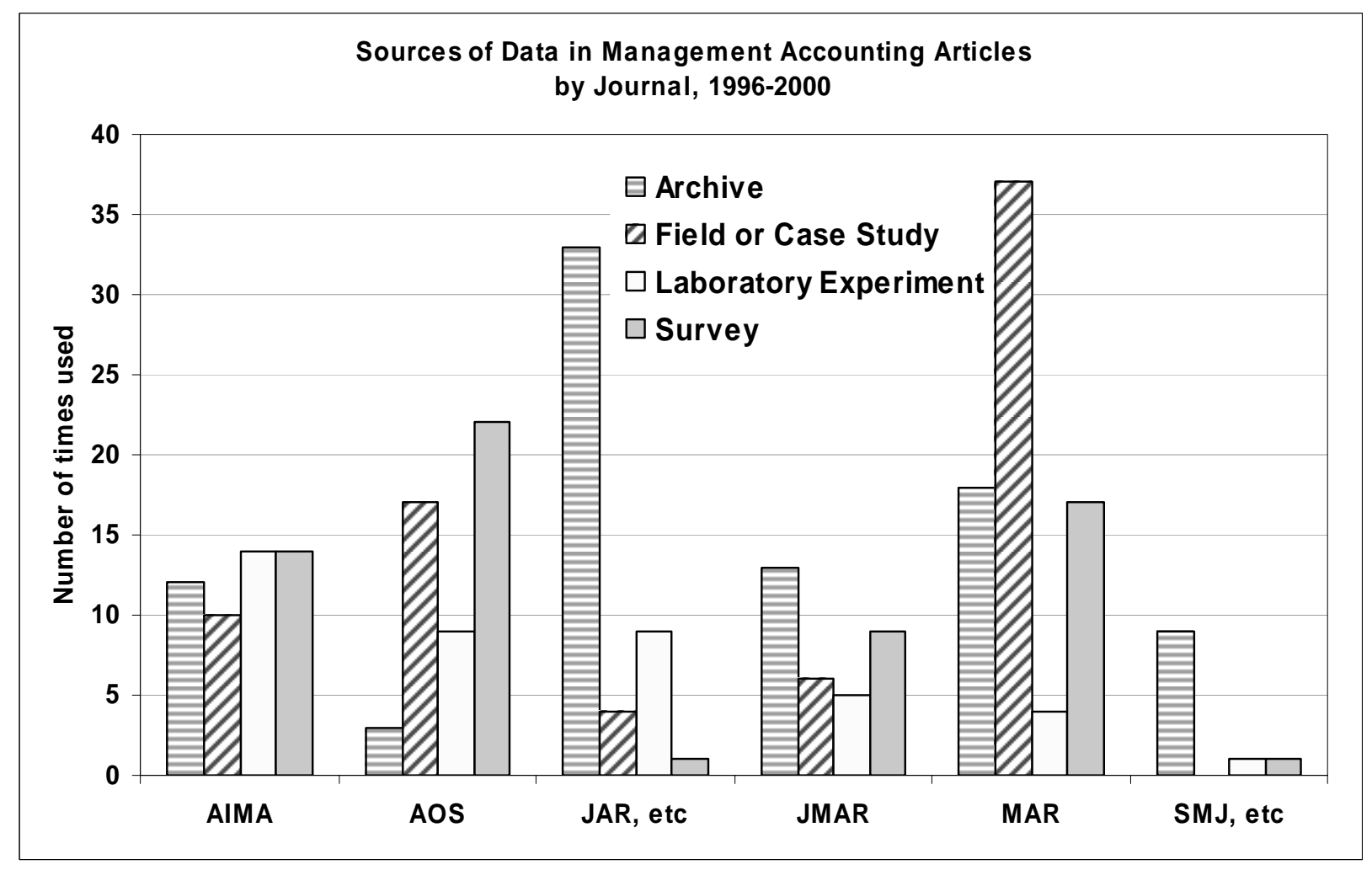




\section{Appendix: Practice-oriented Research Questions}

\begin{tabular}{|c|c|c|}
\hline $\begin{array}{l}\text { Major } \\
\text { Topic }\end{array}$ & Sub-Topic & Selected Research Questions \\
\hline \multirow[t]{3}{*}{ Budgeting } & Activity based & What are effects of merging $\mathrm{ABC}$ with planning \& forecasting? \\
\hline & Capital & $\begin{array}{l}\text { What is the optimal capital budgeting model for electronic } \\
\text { business? }\end{array}$ \\
\hline & $\begin{array}{l}\text { Planning \& } \\
\text { forecasting }\end{array}$ & $\begin{array}{l}\text { What are the determinants of effective planning and forecasting? } \\
\text { What are effects of merging the BSC with planning \& } \\
\text { forecasting? } \\
\text { What exogenous factors affect sales and cost forecasting? What is } \\
\text { a parsimonious model? } \\
\text { What are the roles of IT \& decision-support systems in improving } \\
\text { planning \& forecasting?" }\end{array}$ \\
\hline $\begin{array}{l}\text { Business } \\
\text { processes }\end{array}$ & & $\begin{array}{l}\text { Which activities in the finance function can be eliminated leading } \\
\text { to reduced costs while maintaining high levels of support and } \\
\text { integrity in the accounting information? } \\
\text { Under what business conditions (e.g., size, industry, strategy, } \\
\text { organization type, etc.) can the "lean support model" be } \\
\text { effectively implemented in the finance function? } \\
\text { Is the reduction in finance costs as a percent of sales "real" or } \\
\text { have the costs and related work simply been shifted to other } \\
\text { areas of the organization? } \\
\text { There is anecdotal evidence supporting initiatives (e.g., corporate } \\
\text { purchasing cards, single consolidated credit card system, } \\
\text { online marketplace) designed to streamline the procurement } \\
\text { system in order to increase efficiency and reduce costs. } \\
\text { Which is most effective? What are the determinants of } \\
\text { effective procurement initiatives? } \\
\text { How does technology play a role in successfully reengineering } \\
\text { business processes such as the travel and expense process? }\end{array}$ \\
\hline $\begin{array}{l}\text { Management } \\
\text { control }\end{array}$ & Alliances & $\begin{array}{l}\text { What is the nature of optimal business partner or exclusive supply } \\
\text { contracts? } \\
\text { What are the determinants of successful or failed alliances? }\end{array}$ \\
\hline
\end{tabular}




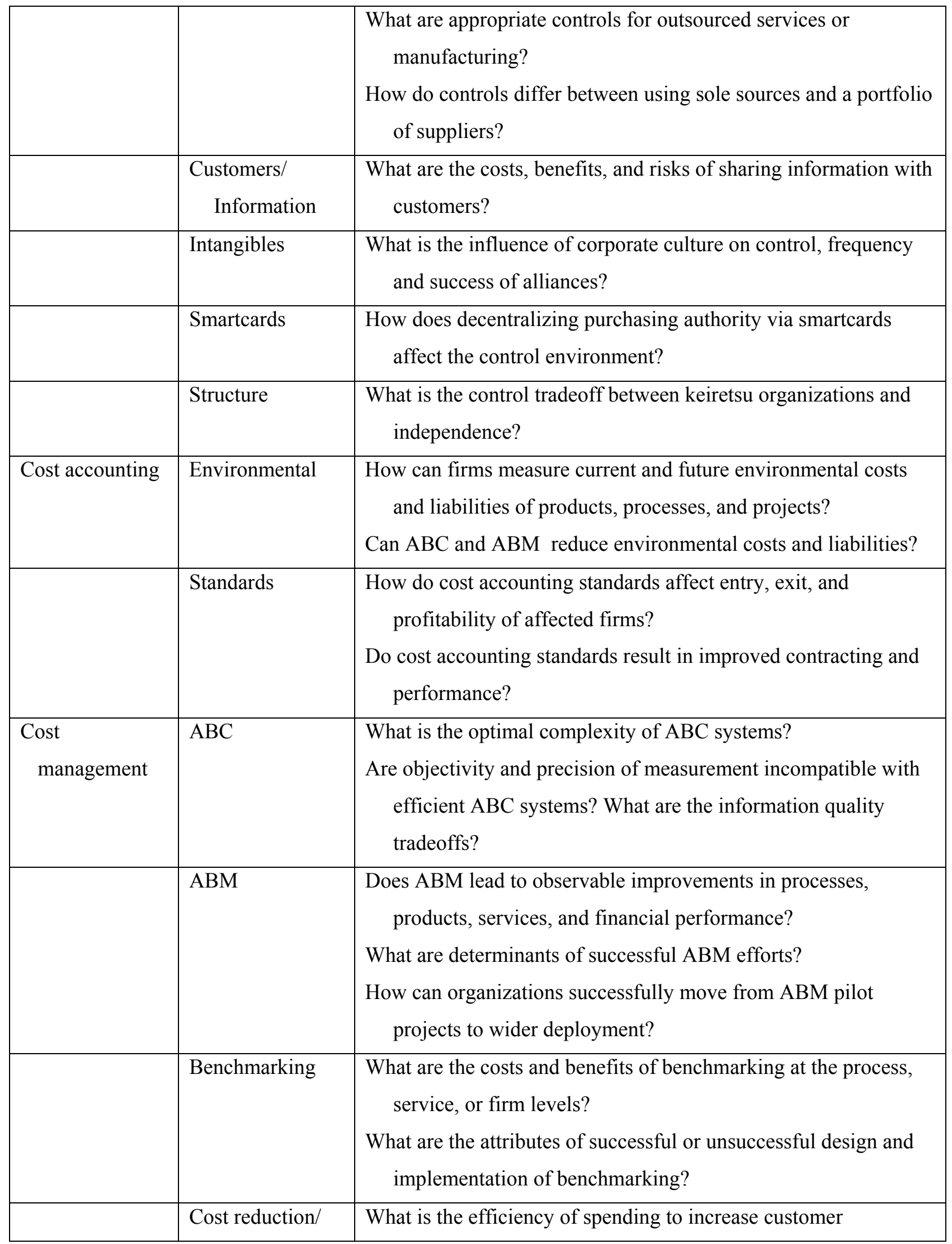




\begin{tabular}{|c|c|c|}
\hline & efficiency & $\begin{array}{l}\text { satisfaction? } \\
\text { What are the effects of IT and organizational changes on } \\
\text { efficiency? } \\
\text { What are the effects of IT on total costs and productivity? }\end{array}$ \\
\hline & Shared services & $\begin{array}{l}\text { What are the efficiencies of locating business services in shared } \\
\text { service centers? } \\
\text { Is ABM necessary to justify shared or outsourced services? } \\
\text { What are the organizational impediments and arguments for } \\
\text { shared services versus distributed or outsourced services? }\end{array}$ \\
\hline & Strategy & $\begin{array}{l}\text { Is the balanced scorecard (BSC) an appropriate tool for } \\
\text { performance evaluation, as well as for strategic planning and } \\
\text { communication? } \\
\text { Are scenarios from financial planning models effective tools for } \\
\text { strategic management? }\end{array}$ \\
\hline \multirow[t]{4}{*}{$\begin{array}{r}\text { Electronic } \\
\text { business }\end{array}$} & Commerce & $\begin{array}{l}\text { What are appropriate management controls, internal controls, and } \\
\text { performance measures for E-business ventures? Do they differ } \\
\text { from conventional business? } \\
\text { What is the optimal capital budgeting model for electronic } \\
\text { business? }\end{array}$ \\
\hline & Internet/WWW & $\begin{array}{l}\text { How do on-line auctions affect transaction costs? } \\
\text { What are the impacts of intranet exchange of accounting } \\
\text { information? } \\
\text { What determines effective intranet exchange of accounting } \\
\text { information? }\end{array}$ \\
\hline & Processing & $\begin{array}{l}\text { What is the impact of electronic processing on the firm's control } \\
\text { environment? }\end{array}$ \\
\hline & XML & $\begin{array}{l}\text { How do accountants successfully use extensible markup language } \\
\text { (XML) to facilitate the exchange and communication of } \\
\text { accounting information? }\end{array}$ \\
\hline Internal control & Controls & $\begin{array}{l}\text { Is the implementation of controls a cost savings or a cost } \\
\text { expenditure (e.g., what are the costs and benefits of certain } \\
\text { control procedures? Which decision models can facilitate this } \\
\text { decision?) }\end{array}$ \\
\hline
\end{tabular}




\begin{tabular}{|c|c|c|}
\hline & $\begin{array}{l}\text { Data security/ } \\
\text { computer } \\
\text { fraud }\end{array}$ & $\begin{array}{l}\text { How do small firms, perhaps without necessary resources to } \\
\text { support data security, implement a strong control } \\
\text { environment? }\end{array}$ \\
\hline & Ethics & $\begin{array}{l}\text { What are the characteristics of an effective ethical environment } \\
\text { (e.g., training programs, codes of conduct, ethical standards, } \\
\text { tone at the top, etc.)? }\end{array}$ \\
\hline & $\begin{array}{l}\text { Fraud awareness/ } \\
\text { detection }\end{array}$ & $\begin{array}{l}\text { Does implementing and adhering to the Internal Control } \\
\text { Framework reduce the prevalence of fraud and positively } \\
\text { impact firm performance? }\end{array}$ \\
\hline \multirow[t]{3}{*}{$\begin{array}{l}\text { Performance } \\
\text { measurement }\end{array}$} & $\mathrm{BSC}$ & $\begin{array}{l}\text { What are the observable impacts of BSC implementation and } \\
\text { use? } \\
\text { What are the effects of alternative means of BSC } \\
\text { implementation? }\end{array}$ \\
\hline & Systems & $\begin{array}{l}\text { How does the design and structure of incentive compensation } \\
\text { systems relate to incidences of fraud? } \\
\text { Can action-profit-linkage chains be designed to capture affects of } \\
\text { investments in intangibles such as training, information } \\
\text { technology and employee satisfaction? }\end{array}$ \\
\hline & Strategic & $\begin{array}{l}\text { What are the appropriate ratios or indicators to measure whether } \\
\text { an organization is meeting its strategic goals, which may be } \\
\text { heavily marketing and customer oriented? Are these indicators } \\
\text { financial, non-financial, or qualitative? }\end{array}$ \\
\hline \multirow[t]{3}{*}{ Software } & Accounting & $\begin{array}{l}\text { What are the costs and benefits of maintaining dual costing } \\
\text { systems to satisfy demands for information related to both } \\
\text { strategic costing management and operational improvements? } \\
\text { What steps can be taken to ensure that a software conversion is } \\
\text { performed competently and efficiently? }\end{array}$ \\
\hline & ERP & $\begin{array}{l}\text { What are the benefits and costs of implementing an enterprise } \\
\text { resource system? } \\
\text { What are the attributes of efficient data mining? }\end{array}$ \\
\hline & Human resources & $\begin{array}{l}\text { What are the effects of HR software on improvements in hiring, } \\
\text { training, retention and evaluation (e.g., linked to BSC }\end{array}$ \\
\hline
\end{tabular}




\begin{tabular}{|l|l|c|}
\hline & & performance models)? \\
\hline Selection & $\begin{array}{c}\text { What characteristics of accounting software packages affect the } \\
\text { efficiency of the organization? }\end{array}$ \\
\hline
\end{tabular}




\section{References}

Anderson, P. F. 1983. Marketing, scientific progress, and scientific method. Journal of Marketing. v47n4, (Fall): 18-31

Atkinson, A.A, R. Balakrishnan, P. Booth, J. Cote, T. Groot, T. Malmi, H. Roberts, E. Uliana, A.Wu, 1997. New directions in management accounting research. Journal of Management Accounting Research: 79-108.

Benbasat, I. and Zmud, R.W. 1999. Empirical research in information systems: the practice of relevance MIS Quarterly v23n1, Mar: 3-16.

Covaleski, M.A., M.W. Dirsmith, S. Samuel. 1996. Managerial accounting research: The contributions of organizational and sociological theories. Journal of Management Accounting Research.

Demski, J.S ; D.E.M. Sappington. 1999. Summarization with errors: A perspective on empirical investigations of agency relationships. Management Accounting Research v10n1, Mar: 21-37 .

Elnathan, D., T. Lin, S.M. Young. 1996. Benchmarking and management accounting: A framework for research. Journal of Management Accounting Research: 37-54.

Institute of Management Accountants. 2000. Counting more, counting less. www.imanet.org/content/publications_and_research/IMAstudies/moreless.pdf

Ittner, C.D., D.F. Larcker. 2001. Assessing empirical research in managerial accounting: A value-based management perspective. Journal of Accounting and Economics.

Ittner, C.D., D.F. Larcker. 1998. Innovations in performance measurement: Trends and research implications. Journal of Management Accounting Research: 205-238.

Kaplan, R. S. 1998. Innovation action research: Creating new management theory and practice. Journal of Management Accounting Research: 89-118.

Kaplan, R. 1983. Measuring manufacturing performance: A new challenge for management accounting. The Accounting Review: 686-705.

Kaplan, R. 1986a. Accounting lag: The obsolescence of cost accounting systems. California Management Review, Winter.

Kaplan, R. 1986b. The role for empirical research in management accounting. Accounting, Organizations and Society v11: 429-52.

Kaplan, R. and T. Johnson. 1987. Relevance Lost! The Rise and Fall of Management Accounting. Harvard University Press.

Leisenring, J. J. and L. Johnson. 1994. Accounting research: On the relevance of research to practice. Accounting Horizons v8n4, Dec: 74-79. 
Lev, B. 1989. On the usefulness of earnings and earnings research: Lessons and directions from two decades of empirical research. Journal of Accounting Research. v27 Supplement: 153-92.

Lev, B. and P. Zarowin. 1999. The boundaries of financial reporting and how to extend them. Journal of Accounting Research. v37n2: 353-387.

Malina, M. A. and F. H. Selto. 2001. Communicating and controlling strategy: An empirical study of the effectiveness of the balanced scorecard. Journal of Management Accounting Research 13: 47-90.

Miles, M. and A. Huberman. 1994. Qualitative Data Analysis: An Expanded Sourcebook. Thousand Oaks, CA: Sage Publications.

Shields, M. D. 1997. Research in management accounting by North Americans in the 1990s. Journal of Management Accounting Research: 3-62. 